\title{
A conversation with Elaine Fuchs
}

$T_{1}$ he cell biologist Elaine Fuchs of the Rockefeller University is best known for revolutionizing the molecular and genetic study of skin. Her research has shed light on dermatologic disorders and all aspects of skin growth and regeneration. Her more recent work in stem cell biology has revealed broad paradigms that regulate tissue regenerative stem cells across the body, and the mechanisms she has described have major ramifications in cancer and regenerative medicine. Watch the full interview with Fuchs (Figure 1) on the JCI website: https://www.jci. org/videos/cgms.

JCI: Where did you grow up?

Fuchs: I grew up in a small town just outside of Chicago, surrounded by fields of corn and trees. I grew up with a father who was a geochemist, working on extraterrestrial minerals. He looked at the lunar samples, there was nothing there that wasn't found on Earth, whereas meteorites coming from billions of miles away to hit the earth were gold mines for a geochemist of his expertise.

JCI: Did he impact your trajectory?

Fuchs: To some extent, yes. Not through his geochemistry or his electron diffraction patterns, but through his ability to recognize rocks that would contain fossils. When I was young, he took my sister and me to the quarries around the Chicago suburbs to collect rocks. He'd put a few rocks in our bags that he knew would contain fossils, unbeknownst to us. He would then crack open our rocks to let us see the fossils. Regarding careers, my father thought I would be a good secretary or elementary school teacher. On the other hand, my father's sister was not admitted into medical school and became a technician at Argonne National Laboratories. She was an early pioneer in the feminist movement, and she had a huge impact on my confidence as a woman.

JCI: How did you decide to major in physical chemistry at the University of Illinois?

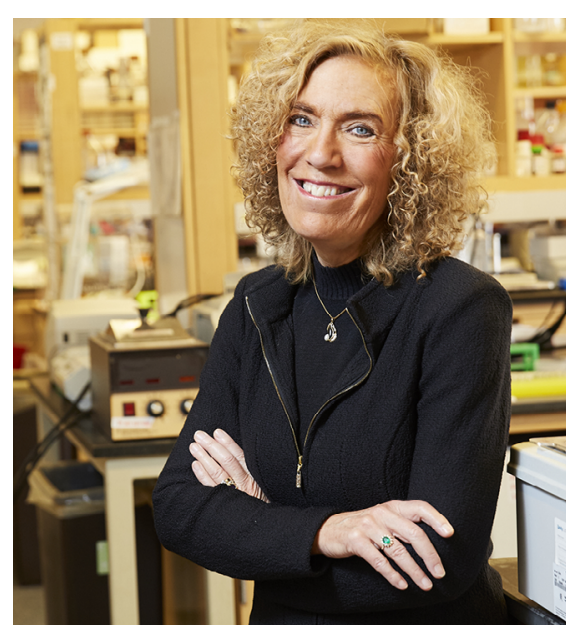

Figure 1. Elaine Fuchs.

Fuchs: Back when I was a high school student, I went to my dad and asked if I could apply to different universities. He asked me to come up with a several-thousand-dollar-a-year reason as to why I wanted to go anywhere besides the University of Illinois where I would get a scholarship, or the University of Chicago where as his daughter, I had a tuition break, because he had been a student there. Since everyone in my family (except my mother) had gone to the University of Chicago, I rebelled and went to the University of Illinois.

Ironically, I never took biology the whole time I was at university. I got hooked on physics and physical chemistry, and I loved it. During this time, I was also active in Vietnam War protests.

JCI: You applied to the Peace Corps ... but ended up in graduate school.

Fuchs: I was intrigued by Chile because Salvador Allende was in reign. Chile had a Marxist government, and yet they also had a 200-year history of democracy. I started to read about Allende and Chile and thought I would really like to go to there. I put all the measures in place and then got my Peace Corps notice: Uganda. Idi Amin was the President and was a tyrant. He jailed and then kicked out all the Peace Corp workers six months after I would have gotten there had I chose that path. My default pathway was graduate school, and this seemed like the best option.

JCI: How did you choose Princeton and biochemistry for your $\mathrm{PhD}$ ?

Fuchs: Fortunate naiveté. I hadn't really carefully planned out what I wanted to do; I was so convinced that I wasn't going to be going to graduate school. I did well at the University of Illinois, but had I known just how exceptional the scientists were who were just starting at the time at Princeton and moving up through the ranks, I probably would have been too intimidated.

I needed to work with someone who could teach me how to do well-controlled experiments and to think like a biologist. My PhD thesis in Charles Gilvarg's lab was on bacterial sporulation. I looked at how bacterial spores transitioned to a vegetative state, and how they broke down their cell wall and had to rebuild one that was compatible with cell division. It was looking at how cells transition from a quiescent state to an actively proliferating state. That's a thread that goes through my whole career.

JCI: You transitioned to Howard Green's lab at MIT and mammalian epithelial biology.

Fuchs: I heard a lecture by him when I was at Princeton, wherein he described putting into culture a piece of human skin, resulting in cells that he could passage endlessly without their losing their ability to differentiate and make skin. To me that was phenomenal. He didn't call them stem cells at the time, but these were the very first stem cells ever cultured.

JCI: Did you think you were going to stay on the academic professorial path?

Fuchs: I did not think I had the ability. As I was developing as a postdoc at MIT, I started to get the sense that I really did like biology. At that point, I can remember thinking, "Well, if one day I have a little laboratory in some small college, maybe with a student or two, that might be something that would be really satisfying."

JCI: And yet you ended up at the University of Chicago for your first faculty position.

Fuchs: It's ironic, given that I said I chose definitively not to go there as an undergraduate. My graduate advisor, who 
interestingly enough thought women didn't belong in science, suggested that I apply. He had gotten an invitation to submit a nomination, and I don't think he really thought I would get the job. I was one year into my postdoc, so I really was not looking for a job. I treated it as a free trip home to visit family. Still, I prepared, taking it as my trial run for whenever I was going to properly apply. I can only look back and wonder why they ever gave me the job, but I think they were impressed when they asked me where else I was applying, and I said, "Nowhere," and I think they took that as a sign of confidence.

JCI: How did you decide the topic for your lab's path?

Fuchs: That was clear from the get-go from the path of my postdoctoral studies. I had tried two different projects that Howard Green had wanted me to do. One was to find additional growth factors; we had known that EGF was important in propagating the cells in culture. Howard very wisely thought there might be additional growth factors that could stimulate these cells, and there were two places to find them. One was serum and the other was urine. I had a whole bag of collecting vessels to give to all my fellow postdocs and I was fractionating urine and that was not for me and I immediately decided to go in a different avenue. If I had kept going, maybe I could have been Joan Massagué and discovered TGF $\beta$ but no, I wanted to look at gene expression in these stem cells.

I wanted to know whether there are different genes for the major structural proteins of the skin. That naturally flowed to investigating mRNAs coding for different keratin proteins, which I had discovered were differentially expressed as the stem cells ceased dividing and began to differentiate. The regulations had been lifted on cloning, and I immediately set out to clone the keratin RNAs that I had identified when I was postdoc.

JCI: You were one of the early pioneers to adopt using transgenic mice for study of disease and pioneered the technique of reverse genetics.

Fuchs: I think this reflects my lack of training. I never took a genetics course. The conventional genetic techniques were not only outside of my expertise but also my interest. Human geneticists were choosing their disease and laboriously slogging their way through the genome to find the genetic mutation that causes the disease-once found, it was often unclear how the protein contributed to the disease. Instead, I wanted to start with my protein. What was it doing in cells? To me that was the fun part.

Soon, we had put our mutant proteins in our stem cells in a dish, but we couldn't link this to a human disease. To do so, we thought we might be able to put our mutant genes into the skin of mice to help guide us to the human etiology. It was clear that transgenic and knockout mice were coming on the scene for biological research. We weighed them both and the mutations that we were working on acted in a dominant negative way and so we thought transgenic mice would be best. No one at the University of Chicago was using these approaches, but I phoned the only person in the Chicago area with the expertise, and she kindly allowed us to buy and set up a microscope in her lab and allow my student to learn the technology. Once we had things up and running, we moved back to my lab and set up the technology at the University of Chicago.

JCI: After you'd created a line of mice with mutant keratin, there didn't seem to be much of a phenotype, until a very astute technician in your lab recognized that the mother mouse was eating one of her pups.

Fuchs: Indeed, Linda Degenstein noticed that the mouse being eaten had a skin phenotype. And of course, I knew nothing about mouse behavior: mom mice take a look at all of their newborns and if she sees one that looks damaged, she eats it. She was leaving us all the non-phenotypic pups.

JCI: You matched up the mutation in the mice you rescued from their mother to a human correlate in epidermolysis bullosa. But at the beginning, people didn't necessarily believe you.

Fuchs: There was a bookstore across the street from the lab. We had bought a dermatology textbook and thumbed our way through to diagnose the mice. When our first publication was in press I presented the work for the first time at a meeting. The chair challenged me on stage and said, "I don't know what you've got but it's certainly not epidermolysis bullosa simplex," which had been our diagnosis of the mice. That experience taught me that when you're challenged, you have to be able to cogently explain and defend yourself. In the midst of countering the punches,
Mina Bissell stood up and told the audience, "Look, I don't know if she's right, but science will figure it out. I thought her talk was interesting." John Stanley (then Chairman of Dermatology at UPenn) then stood up and said, "Actually I would make the same diagnosis that Elaine did." That was a turning point in my career, because it made me recognize the importance of facing not-so-friendly fire on the podium and speaking up to justify your science and conclusions. In so doing, others will likely follow, and in this case, they were important people in the field. I think it makes a difference to the whole community.

JCI: What does the next $5-10$ years hold for your lab?

Fuchs: We're really excited about the medical implications of our work. We know where tumor-initiating cells of cancers reside, how they resist chemotherapy, and how they resist immunotherapy. That has told us that if we dig deeper and understand more about these cells and how they resist various different therapeutics that we hit them with, that we can continue to forge new avenues to treat cancers.

Another vein is our work on inflammation, and there we've identified a very interesting memory system that stem cells possess to be able to remember that they've had an inflammatory experience. In psoriasis or atopic dermatitis, and other inflammatory diseases, inflammation often comes and goes and then comes back in the same spots, only more powerful than the first time. We've discovered that part of the reason for this resides in memories within a stem cell's chromatin. If we can uncover the underlying mechanism, perhaps we might be able to erase the memory. We speculate that perhaps in the future, we might be able to develop a memory eraser to be able to apply to the skin to treat inflammatory disorders. To me, the satisfaction is in the mechanism and not commercialization, but ultimately, we'd like to get close enough to pass the baton to commercial interests.

JCI: If you could not have been a scientist, what else do you think would have kept you interested?

Fuchs: Very easy answer, a National Geographic photographer.

\section{Ushma S. Neill}

